Konventionsentwurf der International Law Commission zur Staatenverantwortlichkeit einerseits, ihrem Entwurf eines Kodex über Verstöße gegen den Frieden und die Sicherheit der Menschheit andererseits (letzterer ist im Anhang der Arbeit abgedruckt). Auch sei, so das Ergebnis der Analyse in Kapitel 6, die Stellung des Individuums im Völkerrecht nach 1945 gestärkt. Zusammengenommen hält er deshalb die Entstehung einer allgemeinen Norm individueller Verantwortlichkeit für schwere Menschenrechtsverletzungen für wahrscheinlich und unterbreitet im abschließenden Kapitel 7 auch einen Vorschlag für ihren Wortlaut.

Wie immer man zu dieser optimistischen Einschätzung stehen mag, es bleibt darüber hinaus als weitere skeptische Frage, ob Sungas Zielvorstellung, diese Verantwortlichkeit sei "(a)n effective way to deter human rights violations" (2), so zutrifft. Doch diese tatsächliche Seite des Problems war nicht Gegenstand von Sungas Arbeit. Uber die rechtliche Seite des Problems dagegen fühlt man sich durch Sunga wohl informiert.

Martin List

\title{
Edward McWhinney
}

Judicial Settlement of International Disputes: Jurisdiction, Justiciability and Judicial Law-Making on the Contemporary International Court

Martinus Nijhoff Publishers, Dordrecht / Boston / London, 1991, xix and 189 pp., hardcover, $£ 46.50$

For those who take an interest in the role and activities of the International Court of Justice (ICJ), this book clearly has an attractive title. At the same time it is rather ambitious, and one wonders how all the topics mentioned can be adequately addressed within 159 pages of main text.

The book is dedicated to the late Judge Manfred Lachs from Poland who was on the bench of the ICJ for more than 25 years. During this period Lachs built up invaluable experience and has made landmark contributions to the jurisprudence of the Court. His death on 14 January 1993 is a great loss to the Intemational Court of Justice and to the community of international lawyers at large. McWhinney refers to Judge Lachs as a witness to and a leader in the process of dramatic changes in dominant judicial philosophy within the Court. According to McWhinney, Judge Lachs was "personifying the new judicial thinking" within the Court.

After a foreword which, among other things, points out the historical contradictions in the attitudes of states towards the ICJ, the book contains five chapters dealing with: contemporary conceptions of the role of intemational judicial settlement; the contemporary international judicial process, law and logic and the law/politics dichotomy; the jurisdiction of the ICJ; the independence and representativeness of the International Court of Justice; 
and the contemporary approach to Court jurisdiction and justiciability. After some conclusions and a Table of Principal Cases, four appendices follow containing applicable articles from the League of Nations Covenant, the United Nations Charter, the Statute of the ICJ, and General Assembly Resolution 44/23 on the United Nations Decade of International Law (which was adopted on 17 November 1989 and not 9 January 1990 as is stated in the table of contents, foreword and header of the appendix). One may doubt the usefulness of reproducing these documents; if it is really necessary to consult them while reading the book, the average user of this publication would have them at hand anyway.

Discussions on the role of the ICJ receives new impetus from a case submitted to it after McWhinney completed his book: the case conceming "Questions of Interpretation and Application of the 1971 Montreal Convention arising from the Aerial Incident at Lockerbie" between Libya and the United States and Libya and the United Kingdom, which was submitted to the Court in March 1992. This case, in which the ICJ issued an Order on 14 April 1992 rejecting the Libyan request for provisional measures (1992 I.C.J. Reports, pp. 114-217), received a lot of attention not only because of the highly political aspects of this dispute but also because at the time the case was under consideration of the Court, the UN Security Council was also acting on it (notably by adopting Resolution 748 of 31 March 1992, imposing mandatory sanctions on Libya under Chapter VII of the UN Charter, if Libya by that date had not surrendered two Libyan nationals allegedly involved in acts of intemational terrorism). The remarks of McWhinney in his foreword, Chapter V and Conclusion, on relations between the ICJ, the General Assembly and the Security Council become even more interesting in the light of this recent development. Among other things, he states that the "new international judicial approach (...) is to look to a complementarity of problem-solving competences of the different World Community organs (...) and to seek and foster mutual cooperation in the devising of measures which, if they are to be successful in resolving the World Community problems involved, will have to be interdependent and interrelated." New judicial pragmatism, according to McWhinney, is reflected in a new institutional comity within the United Nations organization, and in obligations of mutual cooperation and mutual restraint inter se on the part of the different UN organs involved. No matter how desirable this approach might be, the lesson we might learn from the Libya case is that in practice we seem not to have reached that stage yet. By adopting a binding resolution under Chapter VII of the Charter (UNSC Res. 748) while the Court was dealing with the case and formulating its Order on the Libyan request for provisional measures, the Security Council in fact barred the Court from going into the substance of the request. For the Court could hardly do anything other than declare that under the UN Charter all parties involved are obliged to accept and to carry out decisions of the Security Council. Thus, Libya's request for provisional measures had lost relevance after the adoption of binding Security Council Resolution 748 which prescribed the required course of action for the states involved, no matter what the previous (legal) situation or circumstances were.

Chapter I examines changing national positions towards the international judicial settlement of disputes, paying particular attention to the attitudes of the USA and the USSR. While 
American constitutionalism and federalism had an important influence on the post World War II development of ideas about international judicial settlement und thus on the ICJ (an element which is certainly not underestimated by McWhinney), the USA gradually changed its attitude and even withdrew its acceptance of the compulsory jurisdiction of the Court in 1985 in reaction to the Court's positition in the Nicaragua Case. In its turn, the USSR under Gorbatchev seemed to go through the opposite process, softening its traditional position of reluctance towards the ICJ. Many Third World states are also taking a more positive attitude than before towards the ICJ, but one might add to McWhinney's remarks that this is not (yet) reflected in an increasing number of acceptances of the compulsory jurisdiction of the Court. McWhinney concludes that, in terms of contemporary comparative legal science and jurisculture, the principle of judicial settlement of disputes is no longer - if it ever was an esoteric, Western, notion.

The second chapter explains how the Court became increasingly pragmatic in its functioning. The South West Africa Judgment of 1966 was a turning point in this regard, as it sparked off the process as a response by the Court to strong negative criticism of the way it had dealt with the case. It heralded a change from a rather legal positivist and formalistic Court, applying a rigid division between law and society and restricting itself to pure application of the law, into an international judiciary committed to the application of international law in its modem, progressive appearance. This entails a more active and dynamic interpretation of the judicial function; an almost symbiotic relationship between international law and intemational society (law in its societal context) and a more pragmatic interpretation and development of intemational law. The sections on the law/politics dichotomy and legal/political (justiciable/non-justiciable) disputes again refer to some relevant case law, including the Nicaragua Case and the Aerial Incident of 3 July 1988 Case between Iran and the USA. On the whole, though, the presentation and analysis of this subject remain a bit superficial and lack a clear direction.

The jurisdiction of the ICJ is dealt with in Chapter III. After discussing the problems relating to jurisdiction of the full Court, McWhinney looks into the relatively new Chamber procedure. A detailed description is given of the intricacies of the formation of the first ever ICJ Chamber, in the Gulf of Maine Case. Despite the fact that, formally, a judgment rendered by a Chamber shall be considered as rendered by the full Court, McWhinney argues that the legal authority of such a Chamber decision will depend on its intellectual persuasiveness and power, its response to changing conditions in the world community, and the legal-cultural balance or representativeness of its composition. Within the International Court of Justice itself opinions seem to differ on the subject.

Chapter IV deals with the independence and representativeness of the Court and its judges. It contains interesting information on judicial independence, disqualifications and especially on the nomination system of ICJ judges. According to the Statute (Article 4), members of the Court shall be elected by the General Assembly and Security Council from a list of persons nominated by the national groups in the Permanent Court of Arbitration. McWhinney rightly points out that this has become a fiction and that in practice the elec- 
tion of judges is often based on political considerations. Should the Statute ever be revised, perhaps this nomination phase should be brought to an end. McWhinney concludes the Chapter with the observation that the ICJ has become a representative tribunal "fully reflecting the legal-systemic, ethno-cultural, political-ideological, and geographical diversity of contemporary United Nations membership". Yet he had earlier signalled that there are still some shortcomings in the representation of Latin America and the Caribbean, Africa, the smaller states in Asia and the Arab World.

The final chapter discusses the political paradox of an ICJ which today is "actively patronised by the very Third World state-clients that once boycotted" it, while the USA which was once the "most vocal champion of the Court and of the principle of international judicial settlement" is now very critical, if not hostile. But the USA stands virtually alone in its criticism of politicisation, bias and so on. International legal culture and attitudes towards intemational adjudication have become increasingly homogeneous. Unfortunately, the "intemationalising" of the Court has not been accompanied by the necessary changes in internal procedures and style of conducting cases. The length and nature of litigation before the ICJ make it a very costly affair. McWhirmey wonders whether, for example, the onehour rule applied by the US Supreme Court as a maximum for oral argumentation for each side in a case, might not be applied by the ICJ. While such a suggestion seems to be somewhat remote from the international law culture, the issue as a whole certainly deserves much more attention than it is getting today. In the choice of counsels appearing before the Court the process of "intemationalising" has not taken place: most of them are from Europe. Here again the ICJ's judges might not have done enough "to dispel the myth (...) that International Law as practised before the Court is an arcane, Western science that can be comprehended only by Westem legal practitioners". Special indulgence for young and inexperienced counsels, as is practised in some national legal systems, could have an encouraging effect.

Although for close observers of the Court there may not be much new to it, McWhinney has written a very readable book which will be especially useful to those who feel a need to reflect and philosophize on the role and work of the International Court of Justice. The great number of issues dealt with in a relatively short book leads to unavoidable jumps from one subject to another, and sometimes the author's statements are not supported by sufficiently convincing arguments or evidence from the practice of the Court: his challenging remarks on the increased pragmatism of the Court in relation to justiciability and jurisdiction are one example. On the other hand, the book benefits from the "inside" information which is given here and there on the functioning of the Court, for example on the role of specific judges in decision-making and drafting, on Chamber procedures and on elections.

Karin Arts 